\title{
FAMILY VALUES IN RUSSIAN AND CHUVASH PROVERBS AND SAYINGS
}

\author{
Klara V. Pushkina ${ }^{1^{*}}$, Aleksey A. Pushkin ${ }^{2}$, Elena A. Tenyakova ${ }^{3}$ \\ ${ }^{1}$ Assoc. Prof., Chuvash State University, RUSSIA, klara-608389@mail.ru \\ ${ }^{2}$ Assoc. Prof., Chuvash State University, RUSSIA, fldh@mail.ru \\ ${ }^{3}$ Assoc. Prof., Chuvash State Pedagogical University, RUSSIA, tene lena@mail.ru \\ ${ }^{*}$ Corresponding Author
}

\begin{abstract}
The paper considers the peculiarities of the verbalization of the concept "Family" in Russian and Chuvash proverbs and sayings in cross-cultural perspective. The processes of social and cultural interaction of the two nations - the Russians and the Chuvash - are determined by the continuous common inhabitancy of the latter in the middle of the Volga river region of Russia. In the focus of the research there are the systems of value attitudes and those of stereotypical ideas about the family as a specific form of the social institute regulating family relations. At all stages of the family formation beginning with matchmaking and further proceeding to engagement and marriage there are certain peculiarities of the relations between the members of the family including the spouses, their children, and the parents and close relatives on both sides. These family relations have been viewed for centuries through the lenses of value attitudes manifested by all family actors' interactions throughout their lives. The value attitudes characterizing the family life and relations originated in the minds of common people in the form of proverbs and sayings to be inherited by forthcoming generations as a general guideline in their family lives. The proverbs and sayings being the part and parcel of national mind have been preserved in the thesaurus of a national language. The comparative analysis of Russian and Chuvash proverbs and sayings on family life and family relations proves that the Russians and the Chuvash equally prioritize family values nurtured on national cultures and traditions. As far as the main family actors in traditional centuries-long monogamous families are spouses, it is stated that the strength of family ties and the well-being of the family depends on their mutual love and respect, and other human virtues. Many proverbs and sayings being instructive in nature are addressed to either both spouses or each of them individually. The attention of addressees is drawn to universal human virtues and qualities inherent to a good spouse. The proverbs and sayings are also aimed to prevent the youth from making a wrong choice. It has been found that the number of proverbs and sayings addressing prospective husbands exceeds considerably the number of those addressing prospective wives both in Russian and Chuvash cultures. The authors argue this is due to the fact that the major burdens and responsibilities of family life in Russia have always been resting on the husband. It is also stated that proverbs and sayings relating to the concept "Family" can be used by contemporary pedagogical science to foster in the children and the youth the spirit of worshiping family values.
\end{abstract}

Keywords: national mind, family values, analysis, proverbs and sayings, family relations, gender, specific features. 


\section{INTRODUCTION}

Nowadays, when the world can no longer live in isolation, one of the most relevant areas of anthropocentric linguistic research is considering national language phenomena in historical and cultural perspectives. Language as a means of transmission of cultural information reflects the culture of the people, their worldview, the peculiarities of their material and spiritual life herewith allowing one to consider linguistics as an obligatory part of humanitarian knowledge forming the personality (Ashmarin, 1928-1950).

Proverbs and sayings have been recorded since long time. Being figurative in meaning these ready-made and clear cut statements have always been used as instructions regulating economic and social relations and activities of people. The proverbs and sayings on "family relations" having a specific form and contents occupy a considerable part of any national thesaurus (Ashmarin, 1928-1950).

In modern society the family is an important component of universal culture that preserves traditional national values. In the context of ongoing social changes resulting in growing of national identity, returning to origins and sources, breaking down stereotypes, changing attitudes towards family values it is very important to preserve the understanding of family as a traditional social institution, i.e. a community of people who are bound by blood kinship, common life and mutual responsibility. In this regard, the study of proverbs and sayings reflecting universal and national family values is of great importance. The selection and analysis of the proverbs and sayings is grounded on the theory of concept in general and that of linguistic concept in particular. The concept is understood as a two-level entity based on non-verbalized and verbalized perception of the objective reality. Family, family relations and family values that exist objectively in human communities are conceptualized but differently in different cultures and languages (Pushkin, Tenyakova, 2015). The word family and the phrases family relations and family values are combined into one concept "Family" in this paper. Thus the study is aimed at showing the way concept "Family" is verbalized in proverbs and saying of the two neighboring peoples - the Russians and the Chuvash, speaking different languages and belonging to different cultures (Dahl, 2006, Ashmarin, 1928-1950, Volkov, 1958). The comparative analysis of Russian and Chuvash proverbs and sayings on family life and family relations proves that the Russians and the Chuvash equally prioritize monogamous family relations and values nurtured on national cultures and traditions. A detailed comparative analysis of the concept "Family" reveals both common and specific features of family life, family relations and family values manifested in the proverbs and sayings (Dahl, 2006, Ashmarin, 1928-1950). It should be noted that in spite of the fact of the close contacts of the two peoples, very often resulting in mixed marriages as well, both the Chuvash and Russian families preserved national stereotypical ideas, customs and traditions they themselves inherited from their ancestors to further pass to coming generations as a general guideline in their family lives.

\section{MATERIALS AND METHODS}

The choice of the materials and methods of research are determined by the aim to show the characteristics of the two unrelated languages by revealing common and peculiar features in them. A theoretical analysis of the domestic and foreign scientific literature allowed us to determine the methodological foundations and conceptual ideas of the study. The method of analogy and that of the systematic approach were used in analyzing linguistic material in the form of Russian and Chuvash proverbs and sayings relating to the concept "Family" (Dahl, 2006, Ashmarin, 1928-1950). The systematic approach revealed the most common linguistic and cultural patterns of understanding family relationships in the Russian and Chuvash languages. The synergetic approach, according to which complex open systems are viewed as self-organizing, was used to study the evolution of historical and cultural traditions developed in the two unrelated languages. Using empirical methods, in particular observation, the results obtained might be used in developing an academic course "Current Issues of Modern Linguistics" as well as in general and comparative linguistics, writing diploma projects, etc.

People's wisdom and centuries-old experience are transmitted from generation to generation through proverbs and sayings, which are an integral part of their everyday life. The proverbs and sayings express people's great creative and spiritual potential, reflect their worldview, mentality, national traditions and attitudes to other peoples and cultures (Volkov, 2004). It is proverbs and sayings that help us to reveal the mode of people's thinking, opening up wide opportunities for comparative research. The people using the proverbs and sayings in an appropriate communicative situation take it for granted that the latter translate some universal knowledge that can't be doubted in any way.

The mentality or to name it otherwise "mode of thinking" represents not only any specific features but a set of characteristics which determine the worldview inherent to a particular nation. To single out any group of features and give it the name "mentality" is not correct, as the worldview of the people is holistic and organic. 
However, some national features may repeat and dominate, thus allowing us to talk about the characteristic features of the mentality of a given people. At the same time, attention should be paid to the fact that in addition to the general characteristics of the people, it is natural to talk about the mentality of individual groups of people representing the nation.

The proverbs and sayings making up a paremiology heritage of people belonging to a certain nation give one the right to make judgments about the originality and individuality of their national identity. Different peoples in unity represent the entire humanity, which is composed of male and female genders. Interest in gender in social life, language and culture has led to the emergence of gender linguistics. Gender conveys an internally contradictory and at the same time peculiar male-female relations dynamics which is manifested in discourse revealing its universal and specific gender bound characteristics. By gender bound characteristics of discourse we understand all those linguistically relevant gender characteristics expressed either directly or indirectly. The proverbs and saying about family, family relations and values as a rule have explicit gender characteristics referring to either both spouses or one of them, i.e. a male or a female spouse. The elderly people are of the opinion that gender specificity of the proverbs and sayings about family, family relations and values is to be taken for granted, as a pattern to follow in marriage life. In their opinion all ideas about family life, family relations and values expressed in proverbs and saying are aimed at preserving a family as a social institute based on the unity of male and female spouses and their children born in the marriage (Pushkina, 2002). Anyhow at times newly wedded would not like to follow the patterns prescribed in proverbs and sayings because they consider those patterns of family life outdated and hard to follow because they say those patterns originated in times of patriarchal families. The young people think it is unfair to prioritize the role of a male spouse in marriage, keeping a female spouse his inferior. Young female spouses claim for the equality of rights in family life and family relations. More often than not the young get interested in patterns of family life, family relations and values of other nations, considering those patterns might be better than of their people. That is why mixed marriages are quite frequent nowadays. Taking into consideration all the above mentioned and even more possible peculiarities arising around contemporary families we felt a necessity to do a critical analysis of proverbs and sayings about family life, family relations and values in order to see their educational potential, cases of gender priority or superiority, and those of gender discrimination if there are any, and the moral values that are expressed in them. By gender priority or gender prioritizing we understand the functional priority of a particular gender spouse determined by social and cultural traditions having been stereotyped in the minds of people as a pattern of behavior for spouses in marriage life. It should be noted that a priority function of a spouse is usually assessed positively provided his or her role in the family life is that of preserving the family and its well-being in spite of the fact that sometimes family relations may be even harsh. To meet these ends which are important from both theoretical and practical points of view for linguistics and social sciences in general the Chuvash and Russian proverbs and sayings about family, family relations and values are considered in cross-cultural perspective.

\section{FINDINGS}

Out of 998 Russian proverbs and sayings about family life, family relations and values selected from the fundamental dictionary "Proverbs of the Russian People" compiled by outstanding Russian lexicographer V. I. Dahl $658(65.9 \%)$ idiomatic units prioritize a male gender spouse, whereas out of 310 Chuvash proverbs and sayings selected mainly from the 17-volume "Thesaurus of the Chuvash Language" compiled by famous Russian linguist N. I. Ashmarin $269(86.8 \%)$ idiomatic units prioritize a male gender spouse. As for a female gender priority, of all Russian proverbs and sayings $275(27.6 \%)$ idiomatic units prioritize a female gender spouse, whereas of all Chuvash proverbs and sayings 27 (8.7\%) prioritize a female gender spouse. The statistics concerning the male gender spouse priority level in the Russian and Chuvash cultures accounts for the fact that it is higher in the Chuvash culture. The female gender spouse priority level is lower compared with the male gender spouse priority in both cultures, and it is the lowest in the Chuvash culture. It is not possible to determine a gender priority in 65 idiomatic units (6.5\%) of Russian proverbs and sayings and 14 idiomatic units $(4.5 \%)$ of Chuvash proverbs and sayings. This is due to the fact that the gender roles are not prioritized in defiance of their being expressed in proverbs and sayings.

It is well known that a prosperous family life contributes to the formation of a positive image of both women and men, which is also reflected in the proverbs. Quarrels, alcohol abuse and adultery create a negative image of each other. Bearing a set of positive and negative characteristics in mind prospective spouses look for positive traits in each other trying to get rid of or conceal negative ones in themselves. As a matter of fact it is a man that initiates marriage to make a family (Pushkina, 2002). That is why it has been only natural for a prospective male gender spouse to be taught or learn by himself how to make the right choice. There are a number of Russian and Chuvash proverbs and sayings instructing young men not to be mistaken in 
choosing a good wife. At the stage of choosing a wife a positive image of a woman prevails, inspired by the ideal model of a woman-wife, the keeper of the home, conditioned by moral attitudes and requirements approved in the community she lives (Sokolnikova, 1997). The following Russian proverbs show what qualities of a prospective wife should be appreciated by young men, these being virginity, attention, kindness, being industrious, natural, and loved:

Rus. Ne be'ri zhe'nu bo'gatuyu, be'ri, nepo'čatuyu (Don't take a rich wife, take a virginal one).

Ne iś'či 'modnitsu, a iś'či za'botnitsu (Do not seek a fashionable woman, but seek a caring one).

Shei 'śubu tep'lee, a zhe'nu vybi'rai dob'ree (Sew a warmer coat, but choose a kinder wife).

Ho'rošie dlya ho'roših, a ,rabo'tyaščie dlya 'naśego 'brata (The good are for the good, but the industrious are for our brother).

Be'ri zhe'nu ne do'rodnuyu, a pri'rodnuyu (Take not an expensive wife, but a natural one).

Be'ri zhe'nu, čtoby kayatsya, zhiti v lyubvi da ne mayatsya (Take a wife to repent and live in love).

In Chuvash culture it is also young men that initiate marriage. The men have always had a gender priority. They were of the opinion that they could marry any girl. That is why there were no special instructions how to choose a prospective spouse correctly. Anyhow since ancient times the prospective spouses have been suggested that marriage is a very serious landmark in their lives, especially for women:

Chuv. Ka'ča kaii'čen pĕr 'huihă, ka'ča kai'san - çĕr 'huihă (Before marriage one grief, after marriage - one hundred).

Ka'ča kaii'čen mal'tan sar 'kătkă tě'mi çi'ne lar'sa păh'ma 'hušnă (Before getting married, they advised to sit on an anthill - can you stand it?)

'Arlă-'arămăn pĕr çăvar'tan su'ras pu'lat, 'teççĕ (It is said that spouses should spit together=live in harmony).

At the same time the Chuvash people emphasize that every woman should have a husband and every man should have a wife:

Chuv. 'Arsăr 'arăm çur 'tălăh (A woman without a husband is half an orphan).

Úpăšk ka pur - 'purnăç pur (If there is a husband, there is life).

Na'čar kă'na upăš’ka ta xĕr'arămšan 'pysăk 'hătlĕh (Even a poor husband is a woman's strong defence). 'Arămsăr kil-çur'ta il'em kĕ'mest (No beauty will enter the house without a wife)

Although the Chuvash young men did not set very strict requirements to their prospective spouses nevertheless they were very considerate at choosing the mother for their future children:

Chuv. 'Arăm šăpa'ta mar, khyv'sa yvă'taimăn (A wife is not a bast shoe; if it gets bored, it cannot be thrown away).

'Ar yep'le, yiš çap'la (The kind of husband is the kind of family).

Ai'van 'arăm - ar'çyn nu'ši (A foolish wife is a husband's misfortune).

There is a well-known saying among the Chuvash people that is a warning against divorcing and remarrying:

Chuv. Pĕr'reměš 'arăm - 'tură pa'ni, 'ikkĕměš 'arăm - nuša'ran, 'viççĕměš 'arăm - šuytan'ran (The first wife is god-given, the second wife is from want, the third wife is from shaitan).

Old people did not advise to hurry in choosing a bride:

Chuv. Avla'nas ěç're vaska'ma huš'man (One should not hurry to get married).

At the same time, the advantage of family life is pointed out:

Chuv. Yu'ratnă măšăr'pa šăpăr šătakĕn'če te 'yră (Paradise with a sweetheart).

In Chuvash paremiology one of the most important values is family well-being:

Chuv. Kilě'šÿ - kil i'lemĕ (Agreement is the decoration of the home).

Such qualities of a prospective wife as chastity, virtue, modesty, industriousness, ability to manage the household have always been valued very high in the minds of Chuvash people (Volkov, 1958). A prospective wife was also taught to obey her would-be mother-in-law, to endure all possible hardships of 
marriage life, never to complain of anything:

Chuv. Hunyamu'na yu'ras tak, hu'ra ku'rak tări'čen, tări'čen, hu'ran çusa ça'kas pat' (If you want your mother-in-law to like you, get up before the black rooks and put the washed cauldron on the fire).

Hunyamu'na yu'ras tak, sa'la'kayăk tări'čen, tări'čen, sal'ma kas'sa ya'ras pat' (If you want to please your mother-in-law, you have to get up before the sparrows, and let the dumplings into the cauldron).

It should be noted anyhow that some of the Chuvash proverbs and sayings about women have discriminatory and degrading connotations concerning the latter. These proverbs and sayings referring to the ancient patriachal times in the history of the Chuvash people are still being used by way of reminding men of that it is not always easy to know for sure the true intentions of women. The men are warned against trusting their wives, because in the opinion of men women sometimes can do silly things:

Chuv. 'Arăm vil'sen - tep'ri 'alăk khuçěn'čeh (If the wife dies, the other one is waiting outside the door). Ară'ma śani'čen yătta śan (Than trust a wife, trust a dog).

Ară'ma šana'kan ik kuçsăr pulnă (He who trusts his wife will be left without eyes).

'Ură ar'çyn puçta'rat, u'zal hĕr'arăm sala'tat (A good man saves, and a bad woman reels).

Nevertheless, there are proverbs and sayings with positively labeled female gender images thus emphasizing a respectful attitude towards a woman, a wife:

Rus. Muzh'čina 'bez zhe'ny 'tol'ko pol čelo'veka (A man without a wife is only half a man). Veli'čaišee so'kroviśče muzh'činy ye'go zhe'na - po'darok ot 'boga (Man's greatest treasure is his wife: she is a gift from God).

Chuv. Kăma'ka puert ăśśi, 'arăm čun ăś'śi (A good oven is the warmth of the home, and a good wife is the warmth of the soul).

Çueren laśa çul çutti, savnă arăm čun çutti (A good horse is dear on the road, a beloved wife is the light of the soul).

Hĕr 'arămăn 'xĕrĕh 'tĕrlĕ ěç tu'ma ta 'al çi'tet (A woman manages to do forty things at once).

On the whole both the Russian and Chuvash proverbs and sayings prove that the national stereotypes about women formed in the minds of men are positive. The men value the wives for being a good housekeepers, a good wife for her husband, and a good mothers for their children.

Rus. Ho'zyaikoi dom sto it (The house stands safe due to its hostess).

'Dobraya zhe'na 'doblesti 'muzha pro'slavit, a nedo'statki 'sgladit (A good wife will glorify her husband's virtues, and smooth over his faults).

'Dobruyu zhe'nu vzyat - ni 'skuki, ni 'gorya ne 'znat' (With a good wife there is neither boredom, nor sorrow).

Chuv. Çueren laša çul tytat, çumri arăm kil tytat. (A good horse keeps the road, and a good wife keeps the house).

Amăšĕ matur pulsan aššĕ uterieh pulmasan ta ačisem ănaççě (If the mother is a strong person, children grow up to be good people even when the father is not particularly good).

Since ancient times the Chuvash people have had a tradition according to which tenderness and emotional support in relations between spouses are to be shown by the wife mostly (Pushkina, Nikolayeva, 2017). One might say that the lack of tenderness and care from the man towards his wife can be not only a sign of tension between the spouses, but the absence of love as well. As a matter of fact the Chuvash men love and respect their wives. They tend to be reserved because they consider the family relations to be very serious. The men are of the opinion that the well-being of the family they are responsible for rests on their being serious, prudent, and tough-minded with little or almost no feelings and emotions of tenderness. Lack of tenderness and emotions allows them to underline their prioritizing status in the family. The Chuvash have a number of proverbs and sayings confirming this national stereotype:

Chuv. Ar'çyn ěç tu'ma, 'arăm - a'ča păkh'ma (The husband is doing work, the wife is for taking care of the child).

Ar'çyn ěç'pe 'yr 'pulnă, hĕr'arăm - kăkăr'pa, tet (Man is good at work, woman is good at breastfeeding).

Both the Russian and Chuvash men are not deprived of understanding the beauty of a woman by her 
appearance, but when they seek a match for a family life the criterion of woman's beauty is not a major one for them. They accentuate such criteria as her having skills to do work about the house and a set of positive moral and ethical qualities inherent to her:

Rus. S lit'sa ne 'vodu pit', u'mela by piro'gi peč (Not to drink water from her face, she should be able to bake pies).

Chuv. Khi'tre 'arăm an sui'la, un khitri'ne pasa'ra kai'sa su'tas çuk (Do not seek beauty, seek kindness).

Among the features characterizing women in both cultures is that of "excessive talkativeness". As a matter of fact it is not considered to be such a negative feature that might interfere with family relations leading to ruining families. The men usually take it for granted, mostly jokingly. "Excessive talkativeness" of women is reflected in proverbs and sayings in both cultures:

Rus. Za'vyel zhe'nu - za'bud' tiši'nu (Got a wife, forget the silence).

Chuv. Viç khĕr'arăm pĕr pa'sar (Where three women meet, there is a bazaar already).

Khĕr'arăm čĕl'hi 'xĕrĕh ar'çăn (One woman's talk equals forty arshins).

Sometimes men in both cultures assess women's behavior as an extraordinary one and they tend to characterize them using metaphors relating to evil spirits thus underlining the idea of unpredictability of their character. As a matter of fact these metaphors add to the negative connotations of the image of women, but nowadays they are used mostly ironically in both The Russian and Chuvash cultures:

Rus. 'Baba da 'bes o'din u 'nih 'ves (Woman and devil are alike).

Chuv. U'sal khĕrarăm'ran šuyt'tan ta khă'rană (Even the devil scared the woman).

In spite of the fact that some Russian and Chuvash proverbs and saying on family, family relations and values have negative connotations the general idea conveyed by them is that the family is a very important social institute aimed at developing people in harmony with each other, and with the nature.

\section{CONCLUSIONS}

It should be noted that in the Chuvash proverbs saying about the family, family relations and values compared in terms of quantity with those in the Russian language are scarce, though all aspects of family life including the family relations and values that are generally appreciated, and accepted or negated, and rejected are reflected in them. We argue that scarcity of the proverbs and saying on the topic can be explained by the rather closed way of private life of the Chuvash people who tried not to advertise their personal life and not to attract attention to their family life. At the same time the Chuvash people respect the privacy of other people(s). The linguistic culture of the Chuvash language testifies to the closed character of the national mode of life and that of emotional life of the people. The analysis of proverbs and sayings shows that despite the peculiarities of the material and spiritual culture of the two peoples, the understanding of family as a very important social institute is alike. This is a traditional monogamous unity of male and female gender spouses. The analysis of proverbs and sayings revealed similarities and differences between the Russian and Chuvash peoples. The similarities are determined by close contacts in all areas of life on the territory of one state. The differences are determined by the fact that the Russians and the Chuvash initially belonged to different cultures that could not but influence the worldview of these peoples, their styles of life.

\section{REFERENCE LIST}

Ashmarin, N. I. (1928-1950). Thesaurus Linguae Tschvaschorum. Dictionary of the Chuvash Language: in 17 volumes. Cheboksary: Russika.

Dahl, V.I. (2006). Proverbs of Russian people. M: AST, Astrel'.

Pushkin, A.A., Tenyakova, E.A. (2015). Value concepts in the modern paradigm of spiritual and moral education: the linguo-pedagogical aspect. Journal of Modern Problems of Science and Education. No. 2. M.: Russian Academy of Natural Sciences. See https://scienceeducation.ru/ru/article/view?id=22423 Address accessed on December 23, 2021

Pushkina K. V. (2002). The Role of Caregivers in Harmonizing Interpersonal Relationships of Spouses in a 
Modern Young Family. Family in Russia, №1. P. 91-104.

Pushkina K. V. (2002). The Basics of a Harmonious Marriage. Family in Russia, №2. P. 38-48.

Pushkina K. V., Nikolayeva N.V. (2017). Tradition of Upbringing in the Modern Chuvash Family, Problems of Modern Pedagogical Education, № 6(55), p. 161-168.

Sokolnikova E. I. (1997). Ethnopegagogy of a Chuvash Family. Cheboksary.

Volkov G. N. (1958). Chuvash People's Pedagogy: Essays. Cheboksary.

Volkov G. N. (2004). Chuvash Ethnopegagogy. Cheboksary. 